\title{
Detection of Viable Salmonella Typhimurium and Staphylococcus aureus in Coalho Cheese by Real-Time PCR
}

\author{
Juliana França Monteiro de MENDONÇA ${ }^{1}$, Felipe de Oliveira VIEIRA ${ }^{1}$, Isabela FONSECA², João Batista RIBEIRO ${ }^{3}$, \\ Edna Froeder ARCURI ${ }^{3}$, Maria de Fátima BORGES ${ }^{4}$, Cristiano Amâncio Vieira BORGES ${ }^{3}$, \\ Jaqueline Flaviana Oliveira de SÁ ${ }^{5}$, Marta Fonseca MARTINS ${ }^{3 *}$ (iD
}

\begin{abstract}
Real-time PCR (qPCR) has been used for rapid identification of Salmonella Typhimurium and Staphylococcus aureus in dairy foods, but is unable to differentiate viable and unviable pathogens. Ethidium bromide monoazide (EMA), a DNA-intercalating agent, can detect only viable cells because selectively enter cells considered unviable and bind to their DNA, inhibiting its amplification during qPCR. The objective was to establish a protocol for detection of viable Salmonella Typhimurium and S. aureus, experimentally inoculated in coalho cheese, by the use of EMA combined with qPCR. The protocol was effective for the identification of viable Salmonella Typhimurium in coalho cheese but not for the $S$. aureus cells. Concentrations of viable Salmonella Typhimurium cells of $1 \mathrm{CFU} / 10 \mathrm{~g}$ of coalho cheese could be detected. The monoplex protocol enables the rapid and specific identification of viable Salmonella Typhimurium in coalho cheese, making it an alternative method for the quality and safety control of cheeses.
\end{abstract}

Keywords: cell viability; dairy products; DNA-intercalating agents; foodborne diseases; pathogenic microorganisms.

Practical application: Improvement in quality control of foods by the rapid detection of viable pathogens in food matrices.

\section{Introduction}

Due to their compositional characteristics, dairy products are excellent substrates for the growth of various microorganisms that cause foodborne diseases (FBD). According to the World Health Organization, one in 10 people worldwide become ill due to the occurrence of FBD (World Health Organization, 2015). To avoid the occurrence of FBD cases and outbreaks involving dairy products, the use of raw material (raw milk) of good microbiological quality is essential, with pasteurization being one of the most indicated ways to eliminate pathogens in raw milk (Fusco \& Quero, 2014). Normative Instruction No. 30, of June 26, 2001, from the Ministry of Agriculture, Livestock and Food Supply (Brasil, 2001), recommends the use of pasteurized milk for the manufacture of dairy products, including coalho cheese, one of the most consumed cheeses in the Brazilian Northeast (Dias et al., 2015).

Despite its popularity, coalho cheese is often associated with an image of unsafe food (Dias et al., 2015). The low quality of this cheese can be attributed to the use of contaminated raw materials, a lack of hygiene during processing and inadequate product storage, as well as problems related to transportation (Almeida et al., 2013). In all of the above situations, the product may be contaminated with pathogenic microorganisms, thus becoming a health hazard to the consumer (Duarte et al., 2005; Evêncio-Luz et al., 2012; Machado et al., 2011).

Many studies have reported the presence of pathogens in coalho cheese (Borges et al., 2003; Borges et al., 2008; Silva et al., 2012; Sousa et al., 2014; Dias et al., 2015), with Staphylococcus and Salmonella Typhimurium being the most commonly reported microorganisms. In Brazil, these are the pathogens most frequently associated with foodborne outbreaks, accounting for $22.1 \%$ of the FBD outbreaks occurring in the country from 2000 to 2015 (Brasil, 2015). In these outbreaks, the rapid and specific identification of the pathogenic agent is of fundamental importance, both for the sanitary surveillance of the food and for the adequate treatment of the patients affected by FBD.

Several methodologies can be used to identify microorganisms, including microbiological culture and molecular techniques. The methods considered the gold standard for the detection of pathogens in food are those based on microorganism cultivation. Generally, these methods include pre-enrichment and selective enrichment stages, selective and differential plating and confirmation by biochemical and serological tests (Dwivedi \& Jaykus, 2011; Elizaquível et al., 2014). Although they are standardized and relatively low-cost techniques, they are laborious and require considerable time to reach a definitive 
diagnosis (Dwivedi \& Jaykus, 2011; Elizaquível et al., 2014). Thus, the use of more accurate and rapid methodologies is necessary, especially during a food-borne outbreak in which the rapid identification of the causative pathogen is important in the treatment of patients.

Molecular techniques such as Real-Time Polymerase Chain Reaction (qPCR) are more sensitive, specific and fast alternatives to traditional methods. In addition, they offer the possibility of detecting more than one pathogen in the same reaction by performing so-called multiplex reactions. However, qPCR is not able to differentiate viable from unviable cells of pathogenic microorganisms, which is essential in food pathogen analysis. For this purpose, intercalating DNA molecules, such as monoazide ethidium bromide (EMA), can be used together with qPCR to detect only viable cells (Nogva et al., 2003).

EMA is a molecule capable of selectively penetrating cells with damaged membranes and covalently binding to the DNA of the cells after exposure to visible halogen light, thus not allowing DNA amplification to occur during qPCR (Nogva et al., 2003). Therefore, cells with intact membranes do not experience the action of the intercalator since their membranes constitute physical barriers to entry (Rudi et al., 2005a). Thus, the distinction between viable and unviable cells, by the use of EMA, is based on the integrity of the cell membrane. The use of EMA combined with the qPCR technique thus allows the detection of viable pathogens in food in a faster and more sensitive way than the traditional methods that are used (Omiccioli et al., 2009). This technique has been used for the detection and identification of viable pathogenic microorganisms in several types of food, but it has not yet been used for the detection of Salmonella Typhimurium and $S$. aureus in coalho cheese, an extremely challenging food matrix due to the compositional characteristics of the product.

Thus, the objective of the present work was to establish a protocol for the detection of viable Salmonella Typhimurium and $S$. aureus in artificially contaminated coalho cheese using EMA combined with qPCR.

\section{Materials and methods}

\subsection{Preparation of Viable and Unviable Cell Suspensions}

The pre-inoculum was prepared by transferring isolated colonies of Salmonella Typhimurium IAL 1472 and Staphylococcus aureus ATCC 51651 to $3 \mathrm{~mL}$ of Brain and Heart Infusion (BHI) broth (Oxoid Ltd., England). Incubation was performed at $35{ }^{\circ} \mathrm{C}$ for $18 \pm 2 \mathrm{~h}$ under a rotational agitation of $220 \mathrm{rpm}$. Then, $200 \mu \mathrm{L}$ of each pre-inoculum was transferred to $20 \mathrm{~mL} \mathrm{BHI}$ broth before proceeding with incubation at $35^{\circ} \mathrm{C}$ at $200 \mathrm{rpm}$, with the $S$. aureus inoculum being incubated for $3 \mathrm{~h}$ and that of Salmonella Typhimurium for $3 \mathrm{~h} 30 \mathrm{~min}$.

After the incubation period, the bacterial suspensions were divided into $500 \mu \mathrm{L}$ aliquots. Half of the Salmonella Typhimurium and $S$. aureus samples were then submitted to heat treatment in boiling water for $15 \mathrm{~min}$ to eliminate cell viability. The viable and inviable suspensions of Salmonella Typhimurium and S. aureus were plated on $\mathrm{BHI}$ agar to count the colonies (viable) and to confirm the unviability of suspensions that were submitted to heat treatment (data not shown).

\subsection{Inoculation of the pathogens in the coalho cheese samples}

The coalho cheese samples were acquired in local markets in in Fortaleza, Ceará, Brazil. These samples were previously analysed by microbiological tests for $S$. aureus and Salmonella Typhimurium. Those proved to be negative were stored in $10 \mathrm{~g}$ aliquots of cheese in sterile bags.

$89 \mathrm{~mL}$ of $1 \mathrm{X}$ PBS $\left(2.7 \mathrm{mM} \mathrm{KCl} ; 2 \mathrm{mM} \mathrm{KH}_{2} \mathrm{PO}_{4} ; 137 \mathrm{mM} \mathrm{NaCl}\right.$; $10 \mathrm{mM} \mathrm{Na}_{2} \mathrm{HPO}_{4}$ ) were added to the samples and homogenized for the inoculation of pathogens. Then, $1 \mathrm{~mL}$ of the viable and unviable $S$. aureus and Salmonella Typhimurium cell suspensions (previously plated for counting) containing $10^{8} \mathrm{CFU} / \mathrm{mL}$ were added, forming a 'cheese suspension' (macerated cheese $+1 \mathrm{X}$ $\mathrm{PBS}+$ bacterial suspension) at $10^{6} \mathrm{CFU} / \mathrm{mL}$. Subsequently, serial dilutions (up to $10^{-6}$ ) of the cheese suspensions inoculated with viable cultures were performed. The last three dilutions $\left(10^{-4}, 10^{-5}\right.$ and $\left.10^{-6}\right)$ were plated on BHI agar $\left(\right.$ Liofilchem $\left.^{\circledR}\right)$. Samples inoculated with unviable (undiluted) cultures were also plated for confirmation of the cell inviability.

\subsection{Treatment of the pathogen-inoculated cheese samples with EMA}

The EMA (Molecular Probes ${ }^{\circledR}$ - by Life Technologies TM, USA) was added to the coalho cheese samples inoculated with the bacteria at concentrations of $0.5,7.5,10,17.5,25$ and $50 \mu \mathrm{g} / \mathrm{mL}$.

After the addition of the EMA to the samples, they were incubated in the dark for $5 \mathrm{~min}$ at $4{ }^{\circ} \mathrm{C}$ under vigorous agitation (200 rpm). The samples were then transferred to trays containing ice and exposed to $650 \mathrm{~W}$ halogen light (Osram AS, Drammen, Norway) for $5 \mathrm{~min}$ at a distance of $20 \mathrm{~cm}$ from the light source.

\subsection{DNA Extraction and Real-Time PCR}

The DNA extraction of the cheese suspensions inoculated with pathogenic bacteria was performed with the PrepMan ${ }^{\mathrm{TM}}$ Ultra Sample Preparation Reagent (Applied Biosystems ${ }^{\circledR}$, Foster City, CA, USA), following the manufacturer's recommendations.

The qPCRs were performed in multiplex, using TaqMan ${ }^{\circledR}$ Universal PCR Master Mix (Applied Biosystems ${ }^{\circledR}$ - by Life Technologies TM, Foster City, CA, USA) at 1X concentration, $50 \mathrm{nM}$ of each primer for Salmonella Typhimurium, $100 \mathrm{nM}$ each primer for S. aureus, $300 \mathrm{nM}$ of the Salmonella Typhimurium and S. aureus probes and $50 \mathrm{ng}$ of S. aureus DNA and $200 \mathrm{ng}$ of Salmonella Typhimurium DNA, with a final volume of $25 \mu \mathrm{L}$ in each reaction. The sequences of the primers and probes used are listed in Table 1, as well as the efficiency value of each reaction.

The reactions were performed in duplicate in 96-well optical plates sealed with optical adhesive film and amplified on the ABI Prism 7300 Sequence Detection System (Applied Biosystems ${ }^{\circledR}$, USA) equipment. The thermocycling steps used in this work were $2 \mathrm{~min}$ at $50^{\circ} \mathrm{C}, 10 \mathrm{~min}$ at $95^{\circ} \mathrm{C}$ and 40 cycles of $15 \mathrm{sec}$ at $95^{\circ} \mathrm{C}$ and $1 \mathrm{~min}$ at $60^{\circ} \mathrm{C}$. 
Table 1. Sequence of primers and probes used.

\begin{tabular}{llcc}
\hline \multicolumn{1}{c}{ Target species } & \multicolumn{1}{c}{ Sequence of primers $\left(5^{\prime}\right.$ - 3') and probes } & Efficiency & Reference \\
\hline Salmonella Typhimurium & F: ATAAATCCGGCGGCCTGATG & Piknová et al. (2005) \\
& R: TGGTATCGACGCCTTTATCTGAGA & & \\
& P: 5'VIC-TTACACCGGAGTGGATTA AACGGCTGGG-MGB3' & & \\
Staphylococcus aureus & F: TGTAGTTTCAAGTCTAAGTAGC TCAGCAA & Shortle (1983) \\
& R: TGCACTATATACTGTTGGATCT TCAGAA & \\
& P: 5'FAM-TGCATCACAAACAG ATAACGGCGTAAATAGAAG-MGB3' & \\
\hline
\end{tabular}

F: foward primer; R: reverse primer; P: probe.

\subsection{Calculation of EMA Reduction Signal}

The cycle threshold $(\mathrm{Ct})$ values obtained in the $\mathrm{qPCR}$, as well as the efficiency values of the reactions, were used to calculate the EMA Reduction Signal or EMASR (Equation 1). The EMASR represents the fraction of DNA that can be amplified by qPCR in the samples treated with EMA (Rudi et al., 2005a; Rudi et al., 2005b; Nogva et al., 2003). In this equation, "E" represents the amplification efficiency.

$\operatorname{EMASR}=\frac{(1+E)^{\mathrm{C}_{\text {tuntrat }}}}{(1+E)^{\mathrm{C}_{\text {trrat }}}}$

For the efficiency of the reactions, three concentrations of both $S$. aureus and Salmonella Typhimurium (50, 100 and $200 \mathrm{ng}$ /reaction) and three concentrations of the forward and reverse primers of each target (50, 100 and $200 \mathrm{nM}$ ) were tested in monoplex reactions.

\subsection{Calculation of the technique detection limit}

To calculate the technique detection limit, suspensions of pure Salmonella Typhimurium cultures were serially diluted to $10^{-5}$ for subsequent inoculation in the coalho cheese $(10 \mathrm{~g})$ samples and then homogenized with $89 \mathrm{~mL}$ of sterile 1X PBS. Each cheese sample was then inoculated with $1 \mathrm{~mL}$ of each cell dilution, and a manual homogenization was performed. Coalho cheese samples $(10 \mathrm{~g})$ were also inoculated with $1 \mathrm{~mL}$ of pure suspensions of viable and unviable Salmonella Typhimurium cells. For the negative control, samples containing only $10 \mathrm{~g}$ of coalho cheese and $90 \mathrm{~mL}$ of $1 \mathrm{X}$ PBS were used, without the inoculation of viable or unviable cells of the microorganism.

Because of the possible presence of unviable cells in the coalho cheese (due to the previous thermal treatment that must be performed on the raw milk), mixed aliquots of the samples inoculated with viable and unviable cells were prepared for treatment with EMA.

Thus, each $500 \mu \mathrm{L}$ aliquot was formed by $250 \mu \mathrm{L}$ of the sample inoculated with unviable cells and $250 \mu \mathrm{L}$ of the samples inoculated with decreasing concentrations of viable cells. Likewise, aliquots of $500 \mu \mathrm{L}$ of the uninoculated samples - negative controls - were also treated with the EMA.

EMA treatment was performed by adding $25 \mu \mathrm{L}$ of the intercalating dye $(1 \mathrm{mg} / \mathrm{mL})$ to half of the $500 \mu \mathrm{L}$ aliquots formed, resulting in a final concentration of $50 \mu \mathrm{g} / \mathrm{mL}$. The other part of the aliquots was the control (without EMA). The samples were then subjected to the photoactivation of the EMA and DNA extraction, as described in Sections 2.3 and 2.4.

The qPCRs were run in monoplex using TaqMan ${ }^{\circledR}$ Universal PCR Master Mix (Applied Biosystems ${ }^{\circledR}$ ) at 1X concentration, $50 \mathrm{nM}$ of each primer for Salmonella Typhimurium, $300 \mathrm{nM}$ of the Salmonella Typhimurium probe and 200 ng of Salmonella Typhimurium DNA, with a final reaction volume of $25 \mu \mathrm{L}$. The equipment and the thermocycling conditions were the same as those described in Section 2.4.

\subsection{Experimental design and statistical analyses}

All treatments were arranged in a split-plot design in randomized complete blocks (days), with EMA treatments $(0$ or $50 \mu \mathrm{g} / \mathrm{mL}$ ) allocated to subplots and viability treatments (viable or unviable cells after thermal heating) allocated to main plots, with the exception of the limit of detection (LoD) experiment, where the viable cell concentration was the whole-plot treatment. Eight blocks were used in the assay to evaluate the EMA concentration, 11 blocks were used in the inoculated coalho cheese main assay and four blocks were used in the LoD experiment. The qPCR reactions in all experiments were performed in duplicate to verify the intra-assay reproducibility (only those with $\mathrm{CV}<5 \%$ were accepted).

The data of all assays were analysed by split-plot ANOVA using the MIXED procedure of SAS software, version 9.4 (SAS Institute Inc., 2014), and graphs were created in R software, version 3.3.1 (R Core Team, 2016). Significance was established when $\mathrm{p} \leq 0.05$.

\section{Results}

\subsection{Action of EMA on bacteria in coalho cheese samples}

Among the concentrations of EMA tested, $50 \mu \mathrm{g} / \mathrm{mL}$ gave the best results for differentiate Salmonella Typhimurium in viable and unviable cells. However, for the S. aureus inoculated cheese samples, none of the tested concentrations presented satisfactory results since all of them presented an influence of the intercalating dye on the amplification signal of the viable cells (Figure 1), probably due EMA were uptake by $S$. aureus viable cells.

An unexpected difference was observed between the mean $\mathrm{C}_{t}$ values of the viable Salmonella Typhimurium and S. aureus samples treated and not treated with EMA (Figure 2), probably due to the concentration of EMA used $(50 \mu \mathrm{g} / \mathrm{mL})$. 
A.

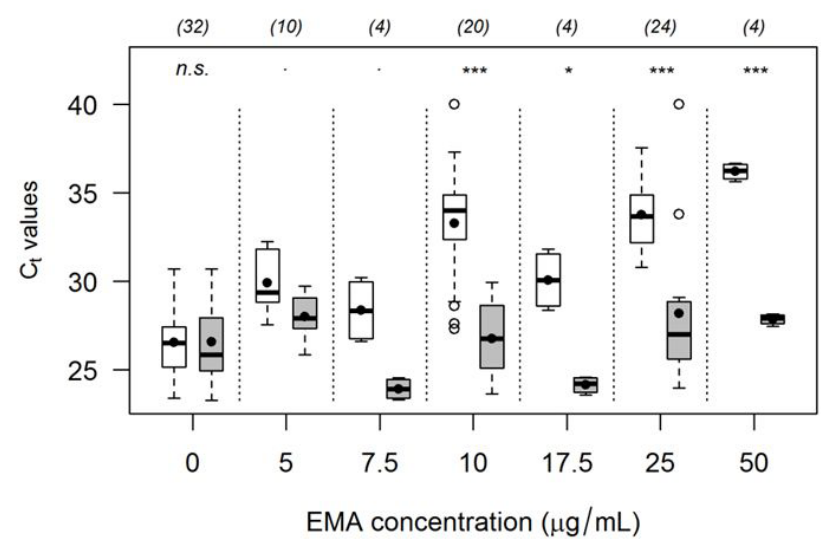

B.

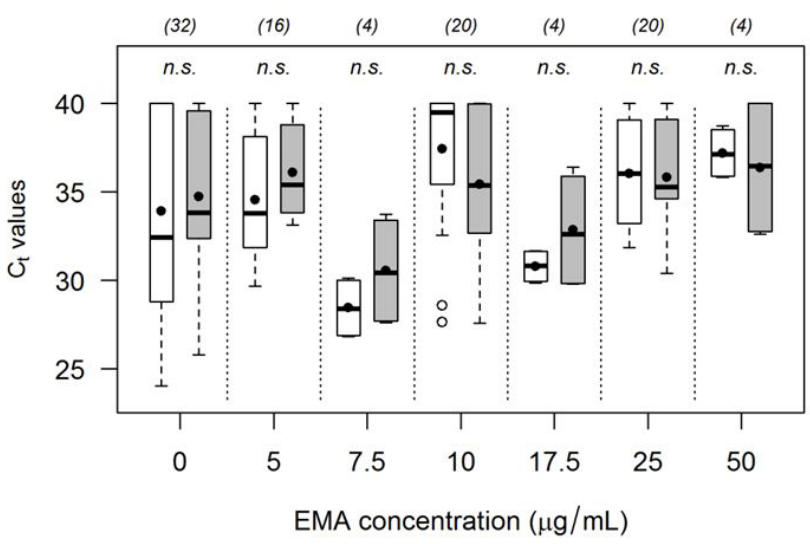

unviable cells $\square$ viable cells

Figure 1. Box plot representation of $\mathrm{C}_{t}$ value distributions at each EMA concentration for the tested pathogens Salmonella Typhimurium (A) and Staphylococcus aureus (B).

A. SalmonellaTyphimurium

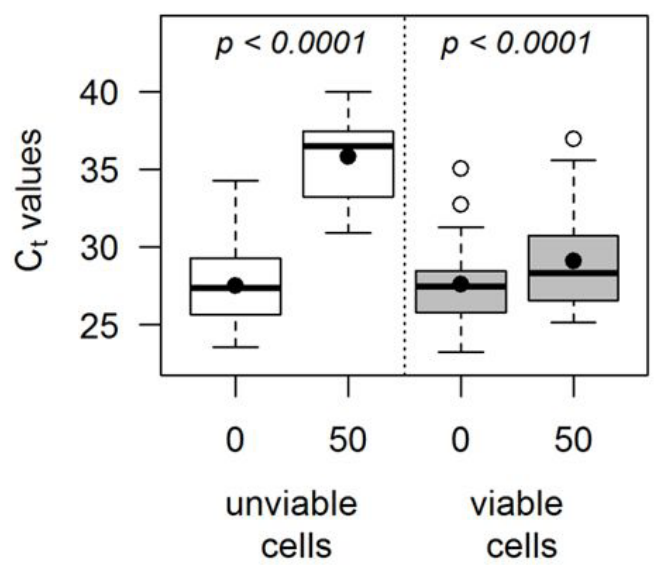

B. Staphylococcus aureus

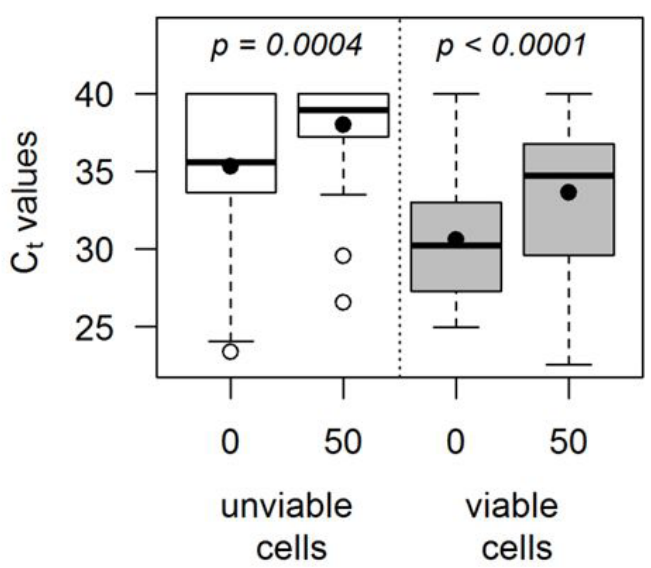

Figure 2. Comparisons of $\mathrm{C}_{\mathrm{t}}$ value distributions between EMA concentration levels for unviable and viable samples of coalho cheese inoculated with Salmonella Typhimurium (A) and Staphylococcus aureus (B); means comparisons by split-plot ANOVA F-test.

The EMASR calculated for the unviable samples of Salmonella Typhimurium inoculated in coalho cheese was 12 times lower than the EMASR calculated for the viable samples. However, for $S$. aureus, this ratio was only approximately 1.8 (Figure 3).

\subsection{Detection limit}

Because the multiplex used in the study (Salmonella Typhimurium and S. aureus) was not efficient for the detection of the cell viability by qPCR combined with the use of EMA in inoculated coalho cheese samples, we decided to continue the study using the coalho cheese samples inoculated with only Salmonella Typhimurium.

For the calculation of the detection limit of the technique, mixed aliquots of viable and unviable cells of Salmonella
Typhimurium inoculated in coalho cheese were used to determine the lowest concentration of viable cells at constant concentrations of unviable cells that the presented protocol is able to detect.

A difference was observed between the mean $C_{t}$ values of the samples treated and untreated with EMA $(50 \mu \mathrm{g} / \mathrm{mL})$ within each viable cell concentration tested (Figure 4; $\mathrm{p}<0.006$ for all concentrations), indicating the ability of EMA to differentiate between viable and unviable Salmonella Typhimurium cells.

As expected, among the samples not treated with EMA, no significant difference was observed between the means of $\mathrm{C}_{t}$ obtained for different concentrations of viable cells (Figure 4; $\mathrm{p}=0.34)$. 

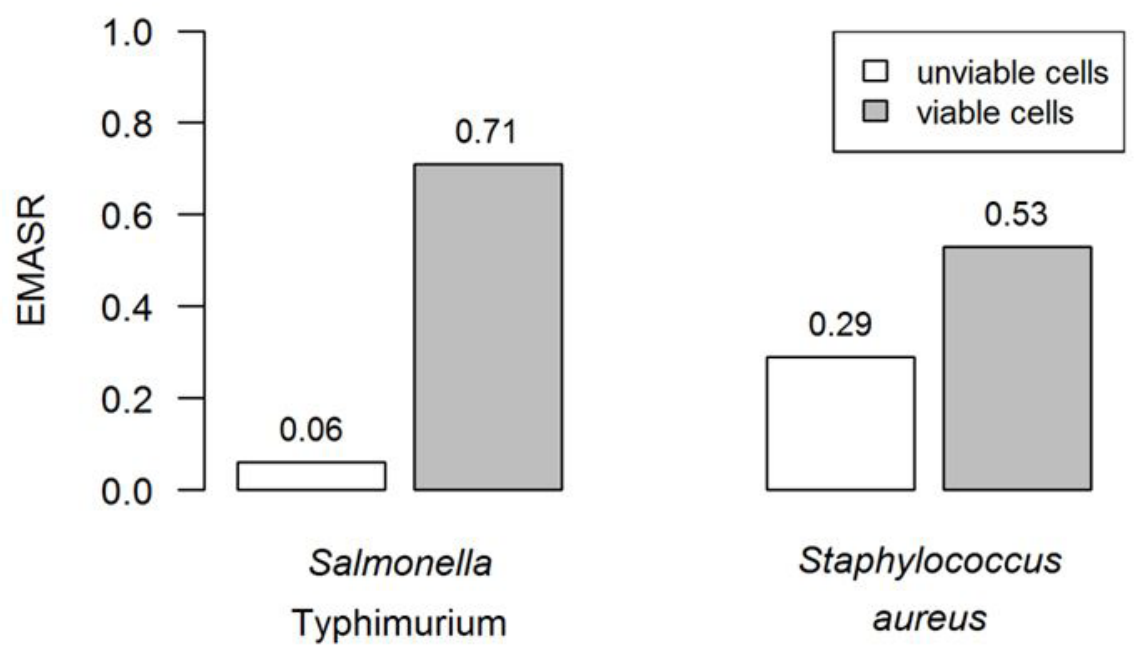

Figure 3. EMASR values calculated for viable and unviable cells of Salmonella Typhimurium and Staphylococcus aureus inoculated in coalho cheese samples. EMASR = EMA signal reduction.

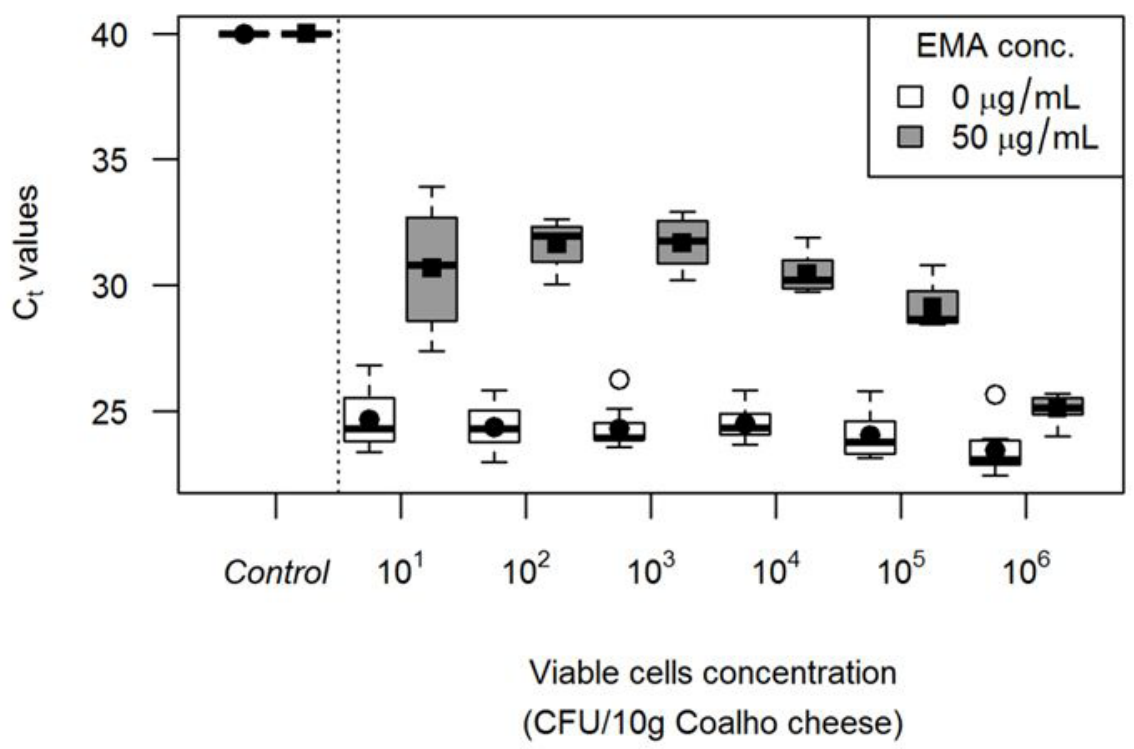

Figure 4. $\mathrm{C}_{\mathrm{t}}$ values distributions obtained for EMA-treated and non-treated samples of coalho cheese, containing $10^{6} \mathrm{CFU} / 10 \mathrm{~g}$ unviable cells, inoculated with increasing concentrations of Samonella Typhimurium viable cells.

\section{Discussion}

\subsection{Action of EMA on bacteria in coalho cheese samples}

Several authors have suggested that the ideal concentration of EMA for viable and unviable cell differentiation is $10 \mu \mathrm{g} / \mathrm{mL}$ (Wang et al., 2009; Minami et al., 2010; Soejima et al., 2011a). In the present study, it was observed that the higher the EMA concentration is (up to $50 \mu \mathrm{g} / \mathrm{mL}$ ), the greater the differentiation of viable and unviable cells for the Salmonella Typhimurium samples. For S. aureus, it was not possible to establish the best concentration for the differentiation between viable and unviable cells. This result confirms that the EMA uptake by viable cells is dependent on the species studied and on the EMA concentration, as reported by Nocker et al. (2006) and Flekna et al. (2007).
The difference observed between the mean $\mathrm{C}_{t}$ values of the viable Salmonella Typhimurium and S. aureus samples treated and not treated with EMA. Figure 2 indicate that the EMA had an influence on the DNA amplification signal of the viable cells of the two pathogens, probably due to the concentration of EMA used $(50 \mu \mathrm{g} / \mathrm{mL})$. As previously mentioned, the action of EMA on viable cells depends on the bacterium, with $S$. aureus being one of the most affected species (Kobayashi et al., 2009).

Complex matrices of food, such as coalho cheese, can negatively influence the efficiency of the EMA treatment since the reduction of the effective concentration of EMA by chemical absorption can occur and organic and inorganic components can interfere in the photoactivation process (Kramer et al., 2009; 
Fittipaldi et al., 2011). Fittipaldi et al. (2012) stated that other factors related to the sample matrix may also negatively affect the efficiency of the EMA. High salt concentrations present in the samples can cause a greater osmotic shock, leading to an increase in signal reduction, in both viable and unviable cells (Shi et al., 2011). Additionally, samples with high turbidity, caused by the presence of organic and inorganic compounds in the matrix, can reduce the light incidence needed for the photoactivation of the intercalator, negatively affecting the EMA efficiency (Fittipaldi et al., 2012). Thus, it can be stated that the characteristics of the sample matrix (coalho cheese) interfered with the uptake of EMA on the unviable cells in this study since EMA was not able to completely inhibit their DNA amplification during the qPCR.

The EMASR calculated for the unviable samples of Salmonella Typhimurium and S. aureus inoculated in coalho cheese again indicates the efficacy of EMA in differentiating viable from unviable Salmonella Typhimurium cells, even within a food matrix, while demonstrating the inability of EMA to produce the same effect on samples inoculated with $S$. aureus.

Based on this information, it was concluded that the multiplex used in the study (Salmonella Typhimurium and S. aureus) was not efficient for the detection of the cell viability by qPCR combined with the use of EMA in inoculated coalho cheese samples. Therefore, we continued the study using the coalho cheese samples inoculated with only Salmonella Typhimurium.

\subsection{Detection limit}

The impossibility of differentiating the mean $\mathrm{C}_{\mathrm{t}}$ values of the samples not treated with EMA is because the unviable cells, present in all samples at a concentration of $10^{6} \mathrm{CFU} / 10 \mathrm{~g}$ of cheese, also undergo amplification during qPCR since there is no EMA action on their DNA.

Thus, although the qPCR technique allied with the use of EMA was able to detect concentrations of viable Salmonella Typhimurium cells as low as $10^{1} \mathrm{CFU} / 10 \mathrm{~g}$ of coalho cheese, it was only possible to significantly differentiate the mean $\mathrm{C}_{t}$ values in cell concentrations greater than $10^{3} \mathrm{CFU} / 10 \mathrm{~g}$ of cheese. Therefore, the $\mathrm{C}_{\mathrm{t}}$ value considered as the limit for differentiation between positive and negative samples in this study was 31.68 . In the Standard Plate Count, the presence of the pathogen could only be detected in the coalho cheese samples inoculated with viable cell concentrations higher than $10^{3} \mathrm{CFU} / 10 \mathrm{~g}$. Thus, the high efficiency and specificity of the protocol developed in detecting low amounts of viable Salmonella Typhimurium cells, even in the presence of unviable cells, can be observed.

In addition to high sensitivity, it is very important to consider the time to be spent on the detection of viable pathogens in food samples. With the traditional culture methods, the confirmation of Salmonella Typhimurium in coalho cheese would take approximately one week, whereas the qPCR technique, combined with the use of EMA, allows the identification of viable cells of the pathogen in similar samples in approximately $36 \mathrm{~h}$. In FBD cases, the rapid identification of the pathogen is of paramount importance, both for control measures and for patient treatment. Thus, once again, the technique used in this study has proven its applicability both for the dairy industry producing coalho cheese and for epidemiological surveillance agencies.

\section{Conclusion}

The protocol established in the monoplex form was effective for the identification of viable cells of Salmonella Typhimurium in coalho cheese samples using EMA combined with the real-time PCR technique. However, the differentiation of viable and nonviable $S$. aureus cells by the use of EMA in coalho cheese was not efficient, once the action of EMA on viable cells depends on the bacterium, with S. aureus being one of the most affected species. Therefore, it was not possible to perform the detection of viable cells of these pathogens, in multiplex, in coalho cheese. The qPCR technique, coupled with the use of EMA, is able to detect viable Salmonella Typhimurium cells in concentrations as low as $10^{1} \mathrm{CFU} / 10 \mathrm{~g}$ of coalho cheese. However, it is only possible to significantly differentiate the mean $\mathrm{C}_{\mathrm{t}}$ values at cell concentrations higher than $10^{3} \mathrm{CFU} / 10 \mathrm{~g}$ of cheese. Therefore, the $\mathrm{C}_{\mathrm{t}}$ value limit for differentiation between positive and negative samples is 31.68 .

\section{Acknowledgements}

To Embrapa/Monsanto (02.11.04.005.00.00) for financial support. JFMF has an Embrapa/Monsanto scholarship, and FOV, IF, and MFM a CNPq scholarship. The authors declare that they have no conflicts of interest.

\section{References}

Almeida, S. L., Paiva, F. G. Jr, \& Guerra, J. R. F. (2013). Representação da produção e consumo do queijo coalho artesanal. Revista Interdisciplinar de Gestão Social, 2(2), 2317-2428. http://dx.doi. org/10.9771/23172428rigs.v2i2.9870.

Borges, M. F., Feitosa, T., Nassu, R. T., Muniz, C. R., Azevedo, E. H. F., \& Figueiredo, E. A. T. (2003). Microrganismos patogênicos e indicadores em Queijo de Coalho produzidos no estado do Ceará, Brasil. Boletim do Centro de Pesquisa e Processamento de Alimentos, 21(1), 31-40. http://dx.doi.org/10.5380/cep.v21i1.1146.

Borges, M. F., Nassu, R. T., Pereira, J. L., Andrade, A. P. C., \& Kuaye, A. Y. (2008). Perfil de contaminação por Staphylococcus e suas enterotoxinas e monitorização das condições de higiene em uma linha de produção de queijo coalho. Ciência Rural, 38(5), 1431-1438. http://dx.doi.org/10.1590/S0103-84782008000500037.

Brasil, Ministério da Agricultura Pecuária e Abastecimento. (2001, Junho 26). Institui o Regulamento Técnico de Identidade e Qualidade de Queijo de Coalho (Instrução Normativa n 30, de 26 de Junho de 2001). Diário Oficial [da] República Federativa do Brasil.

Brasil. Ministério da Saúde. (2015). Doenças Transmitidas por alimentos. Retrieved from http://portalsaude.saude.gov.br/images/pdf/2015/ novembro/09/Apresenta----o-dados-gerais-DTA-2015.pdf.

Dias, J. N., Fontinele, L. L., Machado, S. M. O., Oliveira, J. S., Ferreira, G. P., \& Pereira, A. C. T. C. (2015). Avaliação das condições higiênicosanitárias de leite cru e queijo Coalho comercializados em mercados públicos no norte do Piauí. Revista Saúde e Pesquisa, 8(2), 277-284. http://dx.doi.org/10.17765/1983-1870.2015v8n2p277-284.

Duarte, D. A. M., Schuch, D. M. T., Santos, S. B., Ribeiro, A. R., Vasconcelos, A. M. M., Silva, J. V. D., \& Mota, R. A. (2005). Pesquisa de Listeria monocytogenes e microrganismos indicadores higiênico- 
sanitários em queijo Coalho produzido e comercializado no Estado de Pernambuco. Arquivos do Instituto Biológico, 72(3), 297-302.

Dwivedi, H. P., \& Jaykus, L.-A. (2011). Detection of pathogens in foods: the current state-of-the-art and future directions. Clinical Reviews in Microbiology, 37(1), 40-63. http://dx.doi.org/10.3109/104084 1X.2010.506430. PMid:20925593.

Elizaquível, P., Aznar, R., \& Sánchez, G. (2014). Recent developments in the use of the viability dyes and quantitative PCR in the food microbiology field. Journal of Applied Microbiology, 116(1), 1-13. http://dx.doi.org/10.1111/jam.12365. PMid:24119073.

Evêncio-Luz, L., Lima-Filho, J. V., \& Evêncio-Neto, J. (2012). Occurrence of Salmonella spp. and coagulase-positive Staphylococci in raw eggs and Coalho cheese: comparative study between two cities of Brazil's northeast. Brazilian Journal of Microbiology, 43(4), 1463-1466. http:// dx.doi.org/10.1590/S1517-83822012000400030. PMid:24031977.

Fittipaldi, M., Codony, F., Adrados, B., Camper, A. K., \& Morató, J. (2011). Viable Real-Time PCR in environmental samples: can all data be interpreted directly? Microbial Ecology, 61(1), 7-12. http:// dx.doi.org/10.1007/s00248-010-9719-1. PMid:20632000.

Fittipaldi, M., Nocker, A., \& Codony, F. (2012). Progress in understanding preferential direction of live cells using viability dyes in combination with DNA amplification. Journal of Microbiological Methods, 91(2), 276-289. http://dx.doi.org/10.1016/j.mimet.2012.08.007. PMid:22940102.

Flekna, G., Stefanic, P., Wagner, M., Smulders, F. J. M., Mozina, S. S., \& Hein, I. (2007). Insufficient differentiation of live and dead Campylobacter jejuni and Listeria monocytogenes cells by ethidium monoazide (EMA) compromises EMA/real-time PCR. Research in Microbiology, 158(5), 405-412. http://dx.doi.org/10.1016/j. resmic.2007.02.008. PMid:17449228.

Fusco, V., \& Quero, G. M. (2014). Culture-dependent and cultureindependent nucleic-acid-based methods used in the microbial safety assessment of milk and dairy products. Comprehensive Reviews in Food Science and Food Safety, 13(4), 493-537. http:// dx.doi.org/10.1111/1541-4337.12074.

Kobayashi, H., Oethinger, M., Tuohy, M. J., Hall, G. S., \& Bauer, T. W. (2009). Unsuitable distinction between viable and dead Staphylococcus aureus and Staphylococcus epidermidis by ethidium bromide monoazide. Letters in Applied Microbiology, 48(5), 633-638. http:// dx.doi.org/10.1111/j.1472-765X.2009.02585.x. PMid:19416465.

Kramer, M., Obermajer, N., Bogovic Matijasić, B., Rogelj, I., \& Kmetec, V. (2009). Quantification of live and dead probiotic bacteria in lyophilized product by real-time PCR and by flow cytometry. Applied in Genetics and Molecular Biotechology, 84(6), 1137-1147. http:// dx.doi.org/10.1007/s00253-009-2068-7. PMid:19529931.

Machado, T. F., Borges, M. F., Oliveira, F. E. M., \& Sousa, C. T. (2011). Isolamento e identificação de patógenos em Queijo Coalho. (1st ed.). Fortaleza: Embrapa Agroindústria Tropical.

Minami, J., Yoshida, K., Soejima, T., Yaeshima, T., \& Iwatsuki, K. (2010). New approach to use ethidium bromide monoazide as na analytical tool. Journal of Applied Microbiology, 109(3), 900-909. http://dx.doi. org/10.1111/j.1365-2672.2010.04716.x. PMid:20374413.

Nocker, A., Cheung, C. Y., \& Camper, A. K. (2006). Comparison of propidium monoazide with ethidium monoazide for differentiation of live vs. dead bacteria by selective removal of FNA from dead cells. Journal of Microbiological Methods, 67(2), 310-320. http://dx.doi. org/10.1016/j.mimet.2006.04.015. PMid:16753236.
Nogva, H. K., Drømtorp, S. M., Nissen, H., \& Rudi, K. (2003). Ethidium monoazide for DNA-based differentiation of viable and dead bacteria by 5'-nuclease PCR. BioTechniques, 34(4), 804-813. http://dx.doi. org/10.2144/03344rr02. PMid:12703305.

Omiccioli, E., Amagliani, G., Brandi, G., \& Magnani, M. (2009). A new platform for Real-Time PCR detection of Salmonella spp., Listeria monocytogenes and Escherichia coli $\mathrm{O} 157$ in milk. Food Microbiology, 26(6), 615-622. http://dx.doi.org/10.1016/j.fm.2009.04.008. PMid:19527837.

Piknová, L., Kaclíková, E., Pangallo, D., Polek, B., \& Kuchta, T. (2005). Quantification of Salmonella by $5^{\prime}$-nuclease real-time Polymerase Chain Reaction targeted to fim C gene. Current Microbiology, 50(1), 38-42. http://dx.doi.org/10.1007/s00284-004-4374-8. PMid:15592843.

R Core Team. (2016). R: A language and environment for statistical computing. Viena: R Foundation for Statistical Computing.

Rudi, K., Moen, B., Drømtorp, S. M., \& Holck, A. L. (2005a). Use of ethidium monoazide and PCR in combination for quantification of viable and dead cells in complex samples. Applied and Environmental Microbiology, 72(2), 1018-1024. http://dx.doi.org/10.1128/ AEM.71.2.1018-1024.2005. PMid:15691961.

Rudi, K., Naterstad, K., Dromtorp, S. M., \& Holo, H. (2005b). Detection of viable and dead Listeria monocytogenes on gouda-like cheeses by real-time PCR. Letters in Applied Microbiology, 40(4), 301-306. http://dx.doi.org/10.1111/j.1472-765X.2005.01672.x. PMid:15752222.

SAS Institute Inc. (2014). SAS/STAT ${ }^{\circledR}$ User's guide: Statistics, Version 13.2. Cary: SAS Institute.

Silva, R. A., Bismara, P. A., Moura, R. B., Lima, J. L. Fo, Porto, A. L. F., \& Cavalcanti, M. T. H. (2012). Avaliação da microbiota bacteriana do queijo Coalho artesanal produzido na região Agreste do estado de Pernambuco. Arquivo Brasileiro de Medicina Veterinária e Zootecnia, 64(6), 1732-1738. http://dx.doi.org/10.1590/S010209352012000600044.

Shi, H., Xu, W., Luo, Y., Chen, L., Liang, Z., Zhou, X., \& Huang, K. (2011). The effect of various environmental factors on the ethidium monazite and quantitative PCR method to detect viable bacteria. Journal of Applied Microbiology, 111(5), 1194-1204. http://dx.doi. org/10.1111/j.1365-2672.2011.05125.x. PMid:21848696.

Shortle, D. (1983). A genetic system for analysis of staphylococcal nuclease. Gene, 22(2-3), 181-189. http://dx.doi.org/10.1016/03781119(83)90102-6. PMid:6307819.

Soejima, T., Schlitt-Dittrich, F., \& Yoshida, S. (2011a). Polymerase chain reaction amplifications lengh-dependent ethidium monoazide suppression power for heat-killed cells of Enterobaacteriaceae. Analytical Biochemistry, 418(1), 37-43. http://dx.doi.org/10.1016/j. ab.2011.06.027. PMid:21771573.

Sousa, A. Z. B., Abrantes, M. R., Sakamoto, S. M., Silva, J. B. A., Lima, P. O., Lima, R. N., Rocha, M. O. C., \& Passos, Y. D. B. (2014). Aspectos físico-químicos e microbiológicos do queijo tipo coalho comercializado em estados do nordeste do Brasil. Arquivos do Instituto Biológico, 81(1), 30-35. http://dx.doi.org/10.1590/S1808-16572014000100006.

Wang, L., Li, Y., \& Mustapha, A. (2009). Detection of viable Escherichia coli O157:H7 by ethidium monoazide real-time PCR. Journal of Applied Microbiology, 107(5), 1719-1728. http://dx.doi.org/10.1111/j.13652672.2009.04358.x. PMid:19457030.

World Health Organization - WHO. (2015) The burden of foodborne diseases is substantial. Retrieved from https://apps.who.int/iris/ handle/10665/327488 